\title{
Logical Arguments in the Dialogues (suttas)
}

\section{Fumimaro Watanabe}

On the basis of what we have learned in "The Principles of Reasoning and Forms of Argument in the Early Buddhist Canon")," we would like to examine a few of suttas in the Nikayas and to derive argument forms from them as clearly as possible. So let us start with the Mahätanhāasankhaya-sutta ${ }^{2}$.

In a word this sutta states that the Buddha refuted the heresy of a monk, Sãti by name, who thought that one and the same consciousness transmigrated, not another. But the most important thing in examining the sutta is how the Buddha refuted the heresy of Săti. As we shall see later, the method of the Buddha's refutation is quite logical. The fact would be also inferred from the following words used in the Mahätanhāsankhaya-s. as well as the word Samayappavädaka used in the Pottthapada-s ${ }^{3}$., the Samanamandika-s-s)., etc.:

1. Samayappavādaka Hall for debating on different views.

2. Samanuyuñjati To cross-question, to take up.

3. Samanugāhati To ask for reasons, to cross-examine.

4. Samanubhāsati To criticize, to refute.

Sāti's view is :

In so far as I understand Dhamma (doctrine) taught by the Buddha, it is that this consciousness passes on, transmigrates, not another. The reason for this is that the person who speaks (vado $)^{5)}$, the person who knows and feels (vedeyyo $)^{5)}$, experiences the result of good and bad karmas6).

1) Journal of Indian and Buddhist Studies, Vol. 19-1 (1970), pp. 469-476.

2) M. I, 256-271, Taisho 1, 766b-770a.

3) D. I, 178, Taisho 1, 110a.

4) M. II, 22, Taisho $1,720 \mathrm{~b}$. 
On the other hand, the Buddha's view is :

I indeed stated in various ways that consciousness arises from a cause: There is no arising (sambhava) of consciousness without a cause (añnatra paccayā n' atthi viññanassa sambhavo ti).

And the proof of the above is established, then is followed by taking an example. The proof is:

Whatever consciousness ariese due to a cause, it is identified (sainkham gacchati) by that name:

1. Conditioned by eye and forms, arises consciousness. It is identified by eye-consciousness (cakkhuviñ̃ãana);

2. Conditioned by ear and sounds, arises consciousness. It is identified by ear-consciousness (sotaviñ̃āna);

3. Conditioned by nose and smells, arises consciousness. It is identified by nose-consciousness (ghãnaviññana);

4. Conditioned by tongue and tastes, arises consciousness. It is identified by tongue-consciousness (jivhãviññana);

5. Conditioned by body and touchable objects (phoțhabba), arises consciousness. It is identified by body-consciousness (kãyaviñ̃ãana);

6. Conditioned by mind and mental dhammas, arises consciousness. It is identified by mind-consciousness (manoviñ̃āana).

The example given is in the form of an analogy:

Just as (seyyatha $)$ whenever fire burns due to a cause, it is identified by that name:

1. Conditioned by sticks, burns fire. It is identified by stick-fire (katthaggi);

2. Conditioned by chips, burns fire. It is identified by chip-fire (sakalikaggi);

3. Conditioned by grass, burns fire. It is identified by grass-fire (tinaggi);

4. Conditioned by cow-dung, burns fire. It is identified by cow-dung fire (gomayaggi);

5. Conditioned by chaff, burns fire. It is identified by chaff-fire (thusaggi);

6. Conditioned by rubbish, burns fire. It is identified by rubbish-fire

5) See MA. I, 71 and II, 305.

6) We see the same expression in M. I, 8, Taisho $1,432 \mathrm{a}, 813 \mathrm{~b}, 2,740 \mathrm{c}$, etc. 
(sañkäraggi).

In the Chinese text we see only three kinds of statements, namely: items 2, 3 and 4 mentioned above (see Taisho 1, 767a).

From a logical point of view, analogy is a form of reasoning in which one thing is inferred to be similar to another thing in a certain respect, on the basis of the known similarity between the things in other respects. When one is trying to solve a problem for which no answer is deducible from logical considerations or available knowledge, it is sometimes helpful to look for suggestions in analogous situations in which similar problems of analysis are found. Especially in modern logic, analogies are used in inductive arguments, and although the consideration of analogies often leads investigators down wrong tracks, as well as successful ones, the investigation of appropriate analogies has an important role in the organon of good reasoning.

On the other hand, an example called analogy which is found in the Nikayyas and $\bar{A}$ gamas is always that which can be judged by general knowledge (or that which is well known in a practical manner). In other words, a statement by analogy is only one way to help a listener understand an argument. Let us here compare item 1 in the proof mentioned before and item 1 in the statement by analogy. Both of them may be rephrased as follows to bring out their form:

\section{Statement of proof}

(A) Conditioned by eye and forms, arises consciousness.

(B) It is identified by eye-consciousness.

\section{Analogy}

(a) Contitioned by sticks, burns fire.

(b) It is identified by stick-fire.

We see from the above that the small letter (a) analogously suggests the situation of the capital letter (A), the small letter (b) analogously suggests the situation of the capital letter (B); consequently, the small letters a and $\mathrm{b}$ analogously suggest the situation of the capital letters $\mathrm{A}$ and $\mathrm{B}$. Thus the form of the statements would be: 
Logical Arguments in the Dialogues (suttas) (F. Watanabe)

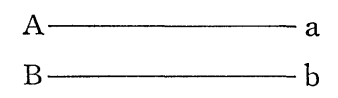

Hence, $\mathrm{B} / \mathrm{A} \longrightarrow \mathrm{b} / \mathrm{a}$

The form B/A—b/a means that the capital letter (B) based on the letter (A) is similar to the small letter (b) based on the letter (a). In other words, the small letters $\mathrm{a}$ and $\mathrm{b}$ are important ways to help a listener understand that the capital letters $\mathrm{A}$ and $\mathrm{B}$ are reasonable. We would say that an analogy which agrees with the statement of proof (or argumentation) is in a sense an analogy based on the method of agreement.

After the argument by analogy, the Buddha continues by explaining to Sāti four kinds of nutriment (āhära), which either maintain living beings or help those seeking birth, and refutes the objection raised against him by Sāti.

Prior to introducing the Buddha's further refutation, we would like here to clarify to a certain extent how the Buddha and his disciples argued and concluded by giving the following verse ${ }^{7)}$ :

Māra: Who made this (human) form (bimbam)?

Where is the maker of the human form?

From whence has it come to be (samuppania)?

Where will it cease (nirujjhati)?

Selā: Neither self-made (attakata) the (human) form is,

Nor other-made (parakata) it is.

Because of a cause (hetu), it has arisen (sambhüta),

By the dissolution (bhanga) of the cause, it will cease.

Just as a certain seed sown in the field

Grows by depending on both the taste of earth and moisture (sineha).

Thus the (five) aggregates, elements (dhatus)

And these six spheres of the senses (äyatanas)

Have arisen because of a cause,

7) S. I, 134, Taisho $1,327 \mathrm{c}$. 
And will cease by the dissolution of the cause.

The word Mãra imports the Devil that is regarded as a temptation or kilesas (poisons) disturbing one's mind, so that Māra's questions above can be considered to be the suspicion which occurred to a nun, Selā by name. Now, we can see that Selā's argumentation is composed of four steps. The first two paragraphs are propositions which deny Māra's questions. This may be called the first argument. The third and fourth paragraphs are propositions that Selā supports to reach a conclusion. This may be called the second argument (or premiss). The fifth and sixth paragraphs are statements by example (or simile). The last four paragraphs are regarded as a conclusion. Selā's argumentation seems to be inductive, because, by stating that one of the five khandhas, aggregates, (which are represented by sabba, all or everything) exists because of a cause, it is stated in the conclusion that the five khandhas exist because of a cause. Thus we see $^{8)}$ :

Form, rüpa, exists because of a cause $\mathrm{F} / \mathrm{c}$

(Sensation, vedanā, exists because of a cause).

(Perception, sañña, exists because of a cause).

(Volition, samkhära, exists because of a cause).

(Consciousness, viñnanana, exists because of a cause).

Hence, everything exists because of a cause. Hence, $(x)(x / c)$

This is, however, not always a consistent argumentation in the Nikäyas. We also see the fact that the five khandhas or the six ayatanas are explained by deductive reasoning, for example ${ }^{9)}$ :

The Buddha said to his monks: Everything is, monks, on fire (sabbam bhikkhave adittam). What everything is on fire? The eye is on fire, objects (rüpas) are on fire, eye-consciousness is on fire, eye-contact (cakkhusamphassa) is on fire, that which arises due to eye-contact, namely: feeling, either happiness or unhappiness or neither-happiness-nor-unhappiness, is also on fire.
8) S. IV, 15-18.
9) S. IV, 19. 
What is called fire is said to be the fire of covetousness, of anger, of delusion, of old age and death, of grief, sorrow, suffering, lamentation and despair. In the above, "everything" means not only eye, but also the other five spheres of the senses. It is, therefore, possible to explain deductively as follows:

Everything is on fire.

Eye is on fire.

Ear is on fire.

Nose is on fire.

Tongue is on fire.

Body is on fire.
( $x$ ) ( $x$ is on fire).

$E$ is on fire.

$\mathrm{Ea}$ is on fire.

$\mathrm{N}$ is on fire.

$T$ is on fire.

$B$ is on fire.

Hence, mind is on fire.

Hence, $\mathrm{M}$ is on fire.

But what we want to emphasize here is that in any argumentation appearing in the Nikayas an example is always indicated. Especially, an example in the form of analogy does not appear to be felt as a weak form of argument. It is also, as pointed out by A. K. Warder ${ }^{10)}$, undoubtedly effective for propaganda purposes. But we see no distinction actually recognized between analogy and strict inference, although in some dialogues analogy is apparently advanced as actual proof, as in the Pāyasi-suttanta where the existence of another world is argued merely on the basis of analogy against a materialist who has attempted to disprove its existence by actual experiments ${ }^{11)}$. But we would say that the Buddha's and his disciples' line of argument is in a sense loose and informal.

We have already discussed the Buddha's first argument and example in the Mahätanhāsankhaya-sutta. But we see his more logical refutation in this sutta. So we would like to examine it and to derive argument forms from it.

The Buddha points out that there are four kinds of nutriment: 1. Kaba-

10) "The Earliest Indian Logic," Proceedings of the 25th International Congress of Orientalists, Vol. 4, (Moscow, 1963), p. 57.

11) D. II, 316-358, Taisho $1,42 b-47 a, 525 a-532 b, 831 a-835 c$. 
linkärăhära=Bodily nutriment, either oḷarika, gross, solid, or sukhuma, fine, minute. 2. Phassāhāra=Nutriment of contact. 3. Manosañcetanāhāra=Nutriment of volition. 4. Viññanāhāa asks the following points of his disciples including Sāti:

I) 1. Do you see, monks, that this has come to be? (Bhütam idan ti bhikkhave passathāti.) (Yes, Sir).

2. Do you see that this is the arising of nutriment? (Tadahärasambhavan ti bhikkhave passathāti.) (Yes, Sir).

3. From the fact that this is the cessation of nutriment, do you see that what has come to be is subject to cessation? (Tadāhäranirodhä yam bhütaim tam nirodhadhamman ti bhikkhave passathāti.) (Yes, Sir).

II) 1. From doubt (kañkha), monks, does the uncertainty (vicikicchä) arise: This has come to be, might it not have? (Yes, Sir).

2. From doubt, does the uncertainty arise: This is the arising of nutriment, might it not be? (Yes, Sir).

3. From doubt, does the uncertainty arise: What has come to be, from the cessation of nutriment, is subject to cessation, might it not be? (Yes, Sir).

III) 1. By seeing as it really is by means of right understanding (sammappaññ) , monks, that this has come to be, is an uncertainty renounced (pahīyāti) ? (Yes, Sir).

2. By seeing as it really is by means of right understanding that this is the arising of nutriment, is an uncertainty renounced? (Yes, Sir). 3. By seeing as it really is by means of right understanding that what has come to be, from the cessation of nutriment, is subject to cessation, is an uncertainty renounced? (Yes, Sir).

IV) 1. For you, is there the absence of uncertainty: This has come to be? (Yes, Sir).

2. For you, is there the absence of uncertainty: This is the arising of nutriment? (Yes, Sir).

3. For you, is there the absence of uncertainty: What has come to be, from the cessation of nutriment, is subject to cessation? (Yes, Sir). 
V) 1. This has come to be. Was this well seen by means of right understanding as it really is? (Yes, Sir).

2. This is the arising of nutriment. Was this well seen by means of right understanding as it really is? (Yes, Sir).

3. What has come to be, from the cessation of nutriment, is subject to cessation. Was this well seen by means of right understanding as it really is? (Yes, Sir).

It seems that the five sections above elucidate how to realize accurately the relationship of "nutriment", "becoming" and "cessation". The fifth section is as a matter of course the final stage to which all Buddhists must reach. In the Chinese text we cannot see the word corresponding to ăhära. Instead, we see the words “如來眞說” (Tathāgata's true words). A translator of this text must have regarded ăhära as araha. The word araha means "to be worthy of". In this sense, the translator presumably imagined the relationship between "worthy" and "Tathāgata" (see Taisho 1, 767 b-c).

Now, the relationship of nutriment, becoming and cessation can be viewed as 'nutriment is the cause of becoming' and 'becoming is the cause of cessation'. Therefore, by using the initial letters N, B and C, the statements of nutriment, becoming and cessation could be expressed by the universal quantificational schemata:

$$
\begin{aligned}
& \text { (x) }(\mathrm{Nx} \supset \mathrm{Bx}) \\
& (\mathrm{x})(\mathrm{Bx} \supset \mathrm{Cx})
\end{aligned}
$$

From this the following schema can be derived:

$$
[(\mathrm{x})(\mathrm{Nx} \supset \mathrm{Bx}) \cdot(\mathrm{x})(\mathrm{Bx} \supset \mathrm{Cx})] \supset(\mathrm{x})(\mathrm{Nx} \supset \mathrm{Cx}) \cdots \cdot(1)
$$

Here we must know this :

(x) $(\mathrm{Nx} \supset \mathrm{Bx})$ implies (x) $\mathrm{Nx} \supset(\mathrm{x}) \mathrm{Bx}$

(x) $(\mathrm{Bx} \supset \mathrm{Cx})$ implies $(\mathrm{x}) \mathrm{Bx} \supset(\mathrm{x}) \mathrm{Cx}$

(x) $(\mathrm{Nx} \supset \mathrm{Cx})$ implies (x) $\mathrm{Nx} \supset(\mathrm{x}) \mathrm{Cx}$

Therefore, we may rest assured that the schema of item 1 is valid. According to the definition "Substitution of quantificational schemata for $p, q$, etc. in valid truth-functional schemata yields valid results ${ }^{12}$ )", we can put 
'( $x$ ) Nx' for $p$, ' $(x) B x$ ' for $q$ and ' $(x) C x$ ' for $r$ and can see the following tautology :

$$
[(\mathrm{p} \supset \mathrm{q}) \cdot(\mathrm{q} \supset \mathrm{r})] \supset(\mathrm{p} \supset \mathrm{r}) \cdots \cdots(2)
$$

As we have learned before, this comes out true under every interpretation of $\mathrm{p}, \mathrm{q}$ and $\mathrm{r}$. Therefore, the schema of item 1 must comes out true no matter what truth values accrue to its components ' $(\mathrm{x}) \mathrm{Nx}$ ', ' $(\mathrm{x}) \mathrm{Bx}$ ' and '( $\mathrm{x}) \mathrm{Cx}$ ' through interpretation of ' $\mathrm{Nx}$ ', ' $\mathrm{Bx}$ ' and ' $\mathrm{Cx}$ '.

It is clear that the Buddha tried logically to inform his disciples that as far as any one depends on nutriment and is subject to cessation, no one has soul (or ego). Rather refer to the discussion on non-soul, let us give attention to the Buddha's further argument. He says :

The four kinds of nutriment have craving as source (tanhanidana), craving as origin (tanhāsamudaya), craving as birth (tanhājātika) and craving as provenance (tanhäpabhava). ......The forces have ignorance as source, ......ignorance as provenance.

And the 12 paticcasamuppaaas in direct order (beginning its exposition at "ignorance") are mentioned. So we could make the above clearer as follows :
1. Ignorance
1. $"$
2. Forces
2. "
3. Consciousness
3. "
4. A sentient body
4. "
5. The six spheres of the senses
5.
6. Contact
6. "
7. Feeling
7. "
8. Craving
8. "
9. Nutriment
9. Attachment
10. Becoming
11. Birth
12. Old age and death

We can realize from the above that item 9 in the first column is related

12) W. V. O. Quine; Methods of Logic, Revised Edition (New York, 1959), p. 97. 
Logical Arguments in the Dialogues (suttas) (F. Watanabe)

to items 10 and 12 (regarded as cessation) in the second column. In other words, it is pointed out that in the first column "nutriment" itself does not exist independently and that it is the direct cause of "becoming" and the indirect cause of "cessation". Furthermore, we see the analytical explanations of the 12 paticcasamuppädas. For instance, concerning the relationship between birth and old age (also, death), the following explanation can be seen :

It has been said: Conditioned by birth are old age and death. Conditioned by birth, monks, are there old age and death or are there not old age and death (jätipaccayā nu kho bhikkhave jarämaranam no vā), how is it as to this (kathaim vā ettha hoti) ? Conditioned by birth, Sir, are old age and death. Thus it is for us as to this: Conditioned by birth are old age and death. In the same way, each paccayäkära (the mode of causes) is analytically elucidated. The above explanation tempts us to try rephrasing into a mixed hypothetical syllogism affirmative. If we use letters $p, q$ to symbolize the statements between the Buddha and monks,

B.: It is true that if there is birth, then

there are old age and death. $\quad \mathrm{p} \supset \mathrm{q}$

B. : Is it true that if there is birth, then

there are old age and death or is it true

that if there is birth, then there are

not old age and death ?

$(p \supset p)$ ? or $(p \supset-q)$ ?

M.: It is, Sir, true that if there is birth,

then there are old age and death. $\quad \mathrm{p} \supset \mathrm{q}$

M. : Thus it is for us to this: It is true

that if there is birth, then there are

old age and death.

$\mathrm{p} \supset \mathrm{q}$

The last words of monks are regarded as the repetition of the Buddha's first words. But we may be allowed to rephrase the last words into two separate statements:

It is true that there is birth. $\mathrm{p}$

It is true that there are old age and death. $q$

Consequently, the Buddha's question and monks' answers become: 
B. : $(p \supset q)$ ? or $(p \supset-q)$ ?

M. : $p \supset q, p$ hence, $q$

In dialogues between the Buddha and his disciples, that which the Buddha explained is always repeated by his disciples. This is in a fair way to develop as mixed hypothetical syllogisms, and as pure hypothetical syllogisms, because the style of argument of the Buddha and his disciples is characterized by using double negatives, and by hypothetical and alternative judgments. In this context, we must note that every statement in the Anumana-sutta is expressed by the term "sace (if) ....., tena (then)......". It is recorded that this sutta was preached by Moggallāna, one of the chief disciples of the Buddha and that there is no reference to the Buddha throughout the whole of the sutta. But since it deals with the admonishing of monks and with self-examination, sentence verbs of the consequent in hypothetical statements mostly have the suffix tabba, which is usually called the future participle. The sense of the future passive participle is generally not simply future but rather imperative or optative: "this must be done", "this should be done", "this ought to be done", also "this can be done13)". Let us see one example in the Anumāna-sutta ${ }^{14)}$ :

If, while a monk is reflecting (paccavekkhamana), he knows thus: 'I am one who is attached to this (mundane) life (sandițthiparamäsĩ), who grasps it tightly (ādhānagāhi $)$ and who cannot abstain from it (duppaținissaggī)', then the monks should strive (vayamitabba, "should be strived" in the : strict sense of the word) to get rid of (these) bad immoral characters (pāpakakkusaladhammas).

By contrast, we see the simile of the above in which a sentence verb in the consequent has no suffix tabba:

Just as a young woman or a young man who is desirous of ornaments reflects them in a mirror or in a bowl of water which is so clear, so pure that his appearance is reflected; if he sees dust or blemish there, he (will) strive (vayyamati) to get rid of it.

13) A. K. Warder; Introduction to Păli, (London, 1963), p. 104.

14) M. I, 99-100. 
It is clear that, among many disciples of the Buddha, some really understood a logical explanation of his teachings and some did not understand it. Therefore, as pointed out in the latter half of p. 6, "the Buddha's and his disciples' line of argument is in a sense loose and informal" involves the fact that the Buddha and his chief disciples avoided explaining Buddhist teachings logically under certain circumstances. A main point here is that the style of argument of the Buddha and his disciples is characterized specifically by using double negatives, and by hypothetical and alternative judgements. In other words, for the Buddha's disciples who clearly understood the real logic of relations in early Buddhism, it must have not been difficult to develop mixed hypothetical syllogisms, pure hypothetical syllogisms and the like.

Now, let us return to the Mahätanhāasankhaya-sutta. After the explanation of the 12 paticcasamuppadas in reverse order, the Buddha states catechetically that if one really understands the dependent origination, one does not have any suspicion of existence, namely:

1. Now, monks, would you, knowing thus, seeing thus, run back to ( $p a$ tidhãvati) the past (pubbanta), thinking: Were we in the past (atitam addhanam), were we not in the past, what were we in the past, how were we in the past; having been what, what did we become in the past? No, Sir.

2. Now, monks, would you, knowing thus, seeing thus, run forward to (ädhävati) the future (aparanta), thinking: Will we come to be in the future (anāgatam addhānam), will we not come to be in the future, what will we not come to be in the future, who will we come to be in the future; having been what, what will we come to be in the future? - No, Sir. 3. Now, monks, would you, knowing thus, seeing thus, come to be internally doubtful now about the present (paccuppannam addhänam), thinking: Am I, am I not, what am I, how am I; from whence has this being come, where is it going? - No, Sir.

Moreover, the Buddha asks several questions, then brings interrogations to a close with the following question: 
Do you not speak of that which of yourselves you have known (ñata), seen (dițtha) and discerned (vidita) ? - Yes, Sir.

In the Chinese text, before the final question above, the Buddha asks many questions which do not correspond to the Pāli text, e. g. On the five anantikakammas (conducts that find retribution without delay, namely: 1. killing one's father, 2. killing one's mother, 3. killing an Arahant, 4. causing disunity in the Buddhist community and 5. injuring the body of a Buddha), On breaking the Buddhistic precepts, and so on"15). At any rate, "that which of yourselves you have known, seen and discerned" is as a matter of course indicative of the dependent origination which the Buddha has explained before in this sutta.

To the Buddha's questions, answering by saying "Yes" or "No" is characteristic of dialogues in the Nikāyas and Ägamas. This is very important in the sense of preparing his disciples against the logical traps inherent in conversion. For example,

1. Is all eye eye-sphere ('eye-sphere' is the sense of sight)?

2. Is all eye-sphere eye?

From the standpoint of Buddhism, the answer to the first question is "No", and the answer to the second question is "Yes". Such questions and answers can be seen especially in one of the Abhidhamma books, the Yamaka. But it can be readily said that these exercises were transmitted from early Buddhism to Abhidhamma Buddhism.

The Mahätanhãsankhaya-sutta is concluded with the explanation of there being two classes of people in this world, namely: one who is ignorant, and who does not realize the origination of entire mass of unhappiness (dukkhakkhandhansamudaya) and the cessation of entire mass of unhappiness (dukkhakkhandhanirodha), and one who is learned, and who does realize both of them. In other words, what the Buddha means in any case is that for each condition this is the cause (hetu), the source (nidana), the origination (samudaya) and the condition (pratyaya) for each thing.

15) Taisho $1,769 \mathrm{a}-\mathrm{b}$. 